\title{
REVIEW
}

\section{Complement Membrane Attack Complex}

\section{New Roles, Mechanisms of Action, and Therapeutic Targets}

\author{
Catherine B. Xie, ${ }^{*}$ Dan Jane-Wit, ${ }^{\dagger}$ and Jordan S. Pober*
}

From the Department of Immunobiology* and the Division of Cardiovascular Medicine, ${ }^{\dagger}$ Yale University School of Medicine, New Haven, Connecticut

\author{
Accepted for publication \\ February 3, 2020. \\ Address correspondence to \\ Jordan S. Pober, M.D., Ph.D., \\ 10 Amistad St., PO Box \\ 208089, New Haven, CT \\ 06509. E-mail: jordan.pober@ \\ yale.edu.
}

\begin{abstract}
The complement membrane attack complex (MAC) is classically known as a cytolytic effector of innate and adaptive immunity that forms pores in the plasma membrane of pathogens or targeted cells, leading to osmolysis. Nucleated cells resist MAC-mediated cytolysis by expression of inhibitors that block MAC assembly or by rapid removal of MAC through endocytosis or shedding. In the absence of lysis, MAC may induce intracellular signaling and cell activation, responses implicated in a variety of autoimmune, inflammatory, and transplant disease settings. New discoveries into the structure and biophysical properties of MAC revealed heterogeneous MAC precursors and conformations that provide insights into MAC function. In addition, new mechanisms of MAC-mediated signaling and its contribution to disease pathogenesis have recently come to light. MAC-activated cells have been found to express proinflammatory proteins-often through $\mathrm{NF}-\kappa \mathrm{B}-$ dependent transcription, assemble inflammasomes, enabling processing, and facilitate secretion of IL-1 $\beta$ and IL-18, as well as other signaling pathways. These recent insights into the mechanisms of action of MAC provide an updated framework to therapeutic approaches that can target MAC assembly, signaling, and proinflammatory effects in various complement-mediated diseases. (Am J Pathol 2020, 190: 1138-1150; https://doi.org/10.1016/ j.ajpath.2020.02.006)
\end{abstract}

Complement membrane attack complex (MAC) was first identified as an effector of the immune system in which certain classes of antibodies trigger assembly of a poreforming complex that inserts into the lipid bilayer of the plasma membrane (the classic pathway), complementing the ability of antibodies to kill cells. ${ }^{1}$ It was subsequently discovered that MAC could also be formed in response to cell-bound mannose-binding lectin (the lectin pathway) or C3 tickover (the alternative pathway). All three pathways converge on the $\mathrm{C} 3 \mathrm{~b}$-mediated proteolytic cleavage of $\mathrm{C} 5$ to form $\mathrm{C} 5 \mathrm{a}$ and $\mathrm{C} 5 \mathrm{~b}$ and the $\mathrm{C} 5 \mathrm{~b}$-mediated sequential assembly of C5b-7, C5b-8, and MAC (C5b-9), referred to as the terminal complement cascade. ${ }^{2}$ Early studies using aged erythrocytes and antibodies against red blood cell membranes to trigger the complement cascade demonstrated the dramatic effects of complement-induced osmotic cell lysis (osmolysis). ${ }^{3}$ The lytic function of MAC serves as an important defense against Gram-negative bacteria, enveloped viruses, and parasites; and genetic deficiencies in terminal complement proteins C5 through C9 predispose to recurrent infections, particularly the Neisseria species. ${ }^{1}$

In contrast to erythrocytes and microbes, nucleated mammalian cells are typically resistant to osmolysis by MAC, although this resistance can be overcome experimentally by activation of (heterologous) complement proteins from a different species. Nucleated cells have multiple defense mechanisms to resist MAC lytic killing. Complement regulatory factors on human cells, including CD46, CD55, and CD59, inhibit early complement activation and amplification, preventing MAC pore assembly. Often, the function of these proteins is species restricted, a phenomenon called homologous restriction, explaining the lytic effects of heterologous complement. ${ }^{4}$ Other defense

Supported by NIH fellowship F30-AI138473 (C.B.X.); and NIH grants T32-GM007205 (C.B.X.), R01-HL141137 (D.J.), R01-HL085416 (J.S.P.), and U01-AI132895 (J.S.P.).

Disclosures: None declared. 
mechanisms include removal from the plasma membrane by shedding of membrane fragments (ectocytosis) or by internalization (endocytosis). ${ }^{5,6}$ In the absence of lysis, MAC may initiate signaling pathways that induce a variety of biological responses consistent with cell activation, including up-regulation of adhesion molecules, ${ }^{7}$ release of proinflammatory cytokines, ${ }^{8,9}$ and increased cell proliferation. ${ }^{10,11}$ MAC-activated cells have enhanced immunogenicity and increased ability to activate adaptive immune responses, which can propagate disease pathogenesis. $9,12,13$

The precise mechanisms of action of MAC on different cell types and its proinflammatory consequences are an area of active investigation. This review discusses how recent advances in MAC structure and formation inform our understanding of how it can modulate cell activation. Recent discoveries elucidating novel proinflammatory intracellular signaling events initiated by MAC that lead to cell activation and altered cell function will also be discussed, and the role of MAC signaling in human diseases will be reviewed. Finally, new potential therapeutic strategies to inhibit the effects of MAC through targeting its assembly or signaling will also be reviewed.

\section{Recent Advances in MAC Assembly and Structure and Implications for Mechanisms of Action}

New understanding of MAC-mediated osmolysis or signaling has come from insights into MAC structure, assembly, and interactions with plasma membrane components. MAC is generated through sequential assembly from the soluble complement proteins $\mathrm{C} 5 \mathrm{~b}, \mathrm{C} 6, \mathrm{C} 7, \mathrm{C} 8$, and $\mathrm{C} 9$. Experimentally, MAC can be assembled using heterologous sera ${ }^{4}$; zymosan-activated sera, which activates complement in the fluid phase by the alternative pathway and in the absence of cell membranes to generate soluble $\mathrm{MAC}^{14}$; sequential addition of recombinant $\mathrm{C} 5 \mathrm{~b} 6, \mathrm{C} 7, \mathrm{C} 8$, and $\mathrm{C} 9$; and high-titer panel reactive antibodies, which react primarily with nonself class I and class II major histocompatibility complex molecules on endothelial cells and assemble MAC by the classic pathway. ${ }^{9,13,15}$ MAC sequential assembly on nucleated cells using minimally diluted concentrations of complement components is largely noncytolytic, ${ }^{16}$ and forms of MAC deposit on but do not fully insert into cell membranes. ${ }^{7}$ The various methods of complement activation lead to MAC structures with differential interactions with the plasma membrane and complement regulatory proteins, leading to differential cytolytic and proinflammatory activities.

Recent studies have visualized the heterogeneity of MAC structures and their varied degrees of membrane insertion and distortion using cryogenic electron microscopy. As C5 is cleaved by $\mathrm{C} 3 \mathrm{~b}$ to yield $\mathrm{C} 5 \mathrm{a}$ and $\mathrm{C} 5 \mathrm{~b}, \mathrm{C} 5 \mathrm{~b}$ rapidly binds C6. On recruitment of $\mathrm{C} 7, \mathrm{C} 5 \mathrm{bC} 6 \mathrm{C} 7$ is stabilized by binding to the outer lamella of the plasma membrane. Recruitment of $\mathrm{C} 8$ leads to formation of the $\mathrm{C} 5 \mathrm{bC} 6 \mathrm{C} 7 \mathrm{C} 8$ (C5b-8) initiator complex that allows for the initial insertion into the membrane. This partially inserted initiation complex acts as a nucleation site and recruits soluble $\mathrm{C} 9$ to propagate pore growth. The incorporation of the first $\mathrm{C} 9$ is a ratelimiting step, which lowers the energy for bending the lipid bilayer, and additional soluble C9 monomers may be recruited after membrane insertion. ${ }^{17}$ Pore formation is rapidly completed in a unidirectional, clockwise oligomerization. ${ }^{18}$ Although multiple plasma-soluble regulatory factors inhibit C 3 and C5 convertase formation, CD59 is the only membrane-associated inhibitor in human cells and acts by inhibition of terminal complement activation. CD59 acts by either binding to the $\mathrm{C} 5 \mathrm{~b}-8$ precursor or after adding $\mathrm{C} 9$ to prevent further oligomerization. ${ }^{18}$ Thus, MAC precursors and terminal complexes have distinct interactions with and do not all transverse the lipid bilayer.

MAC was classically believed to be a rigid transmembrane pore, allowing water and ions to passively traverse and cause osmolysis, as observed in experiments on aged erythrocytes. Recent experiments revealed MAC to be a flexible immune pore with open and closed conformations (Figure 1). Moreover, MAC is not assembled into a symmetric and completely closed ring. Instead, MAC assumes an asymmetrical split-washer configuration composed of three regions: the asymmetric region (C5b, C6, C7, and C8), a hinge region $(\mathrm{C} 7, \mathrm{C} 8$, and two $\mathrm{C} 9)$, and a $\mathrm{C} 9$ oligomer. ${ }^{19}$ In the open conformation, the asymmetric region juts into the lumen to exaggerate the split-washer conformation and MAC has a $30-\AA$ wide chasm traversing the length of the pore (Figure 1A). The asymmetric region can rotate with respect to the $\mathrm{C} 9$ oligomer to vary the curvature of $\mathrm{C} 9$, and the chasm is sealed in the closed conformation (Figure 1B). It is not clear if these different conformations affect the patency of the pore that is formed, but alternative conformations of MAC may differ in their effects on membrane curvature, elimination from the plasma membrane (discussed below), or pore-independent pathways of signal induction. $^{20}$

The plasticity of the MAC pore structure and how MAC interacts with the lipid bilayer have implications for its subsequent mechanisms of action that have yet to be fully characterized. ${ }^{19,21}$ For instance, the membrane-interacting $\beta$-hairpin structures composing the MAC pore differ in length and charge properties. Moreover, the MAC $\beta$-pore barrel and scaffold composition were observed to be highly glycosylated, and glycan removal altered the structural integrity of the $\beta$-barrel and led to irregular pore structures. ${ }^{19}$ Mutational variants of $\mathrm{C} 9$ discovered in patients with the complement-associated disease, age-related macular degeneration, revealed that changes affecting the negatively charged patch on $\mathrm{C} 9$ altered recruitment of $\mathrm{C} 9$ by its positively charged face and the rate of $\mathrm{C} 9$ self-polymerization. ${ }^{19}$ These structural variants, thereby, influence MAC assembly and interactions with target cells, and may also 

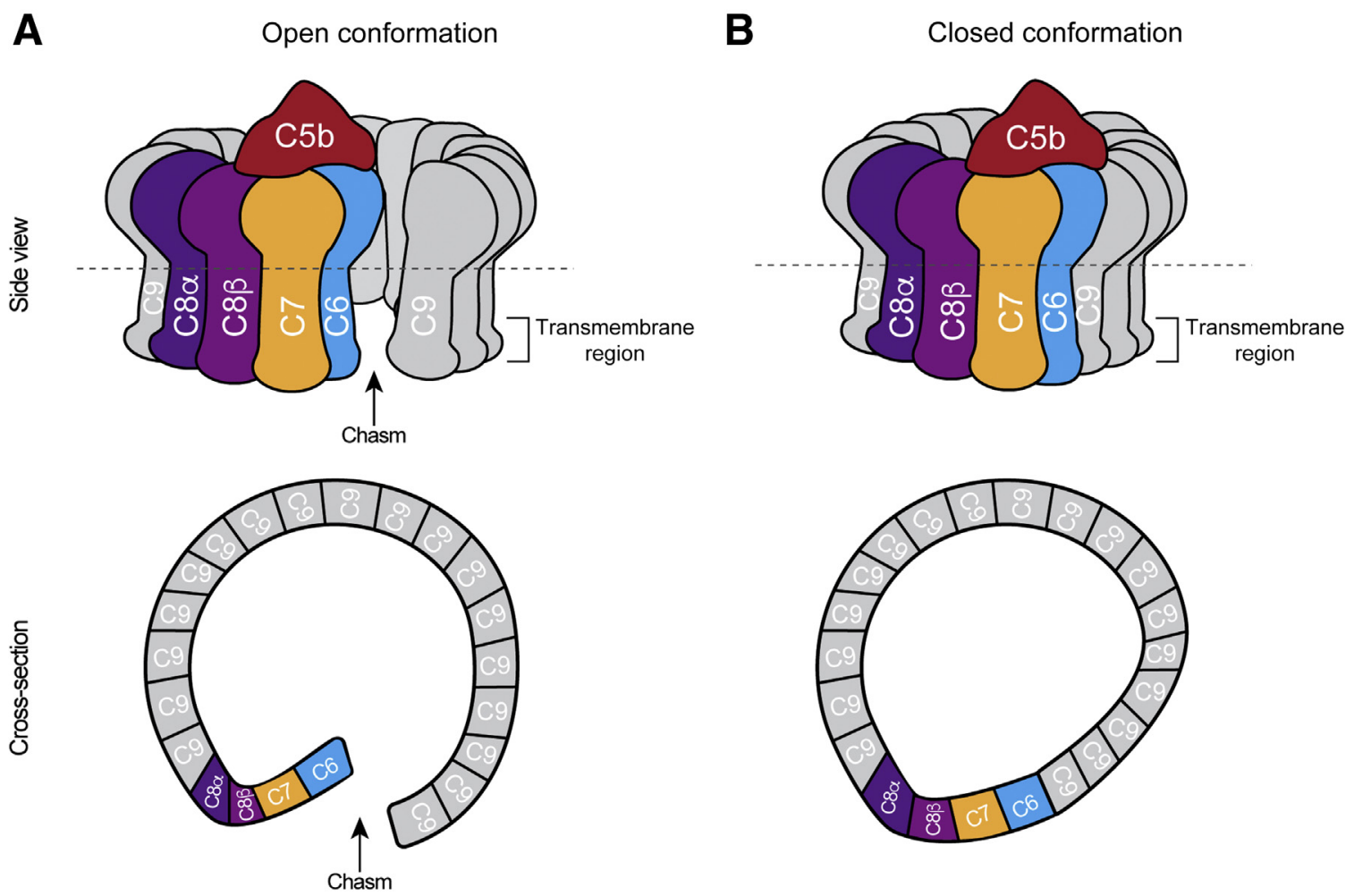

Figure 1 Conformational flexibility of membrane attack complex (MAC) pore structure. A: Open conformation of MAC pore based on cryogenic electron microscopy reconstruction, ${ }^{19}$ demonstrating a split-washer configuration with a $30-\AA$ wide chasm running the length of the pore. The asymmetric region (C5b, $\mathrm{C} 6, \mathrm{C} 7$, and $\mathrm{C} 8$ ) juts into the lumen of the $\beta$-barrel pore by the hinge region (C7, $\mathrm{C}$, and two $\mathrm{C9s})$, as shown in cross-section. B: The chasm is sealed in the closed conformation of MAC pore by the asymmetric region rotating out to meet the C9 oligomer (18 C9 monomers) to vary the curvature of C9 and generating an asymmetric $\beta$-barrel pore. The transmembrane regions are indicated, and the cross-sectional views shown are indicated by the dashed lines in the side views.

alter the efficacy of CD59 inhibition, which associates directly with MAC components to inhibit C9 oligomerization. Although MAC does not have any known surface receptors or lipid dependency for its binding, MAC is observed to be aggregated in specific lipid microdomains and glycosylphosphatidylinositol (GPI)-anchored proteins. ${ }^{22}$ This clustering may be due to the biophysical properties of the $\beta$-barrel pore, asymmetry, or conformations that confer a selectivity. Clustering of MAC on the cell membrane may be a process regulated by the targeted cell to control membrane distortion or destabilization and aid more efficient host cell recovery by MAC endocytosis or shedding.

The heterogeneity of MAC precursors and terminal structures, conformations, and membrane interactions on various cell types are indicative that a single mechanism of action downstream of MAC is unlikely. Further study on what factors mediate conformational changes of the MAC pore and the interplay between the host cell, the various MAC intermediaries and conformations, and the environmental milieu that may influence MAC assembly, elimination, and downstream MAC-initiated intracellular signaling remain to be more precisely elucidated. Human diseaseassociated variants and mutations will be informative in studying abnormalities in MAC assembly, structure, and signaling.

\section{MAC Initiates Intracellular Signaling that Can Induce Cell Activation and Alter Cell Function}

\section{MAC Signaling Initiated by Ion Flux Across the Plasma Membrane}

As a pore-forming complex, MAC insertion in the plasma membrane of a cell can lead to collapse of physiological ion gradients across this barrier. For example, $\mathrm{K}^{+}$ion efflux is a signal for ATP entry and nucleotide-binding oligomerization domain-like receptor family pyrin domain containing 3 (NLRP3) inflammasome assembly (Figure 2A). ${ }^{23}$ At the same time, large increases in $\mathrm{Ca}^{2+}$ ion concentrations in the cytosol can activate prolytic factors, such as calpain, Bcl-2 homology 3 domain (BH3) interacting domain death agonist, receptor-interacting serine/threonine-protein kinase 1 , receptor-interacting serine/threonine-protein kinase 3 , and mixed lineage kinase domain-like protein. ${ }^{24,25}$ Elevated cytosolic $\mathrm{Ca}^{2+}$ ion concentrations also trigger a large number of cell survival promoting events mediated by activation of calcium-binding proteins, such as calmodulin, 


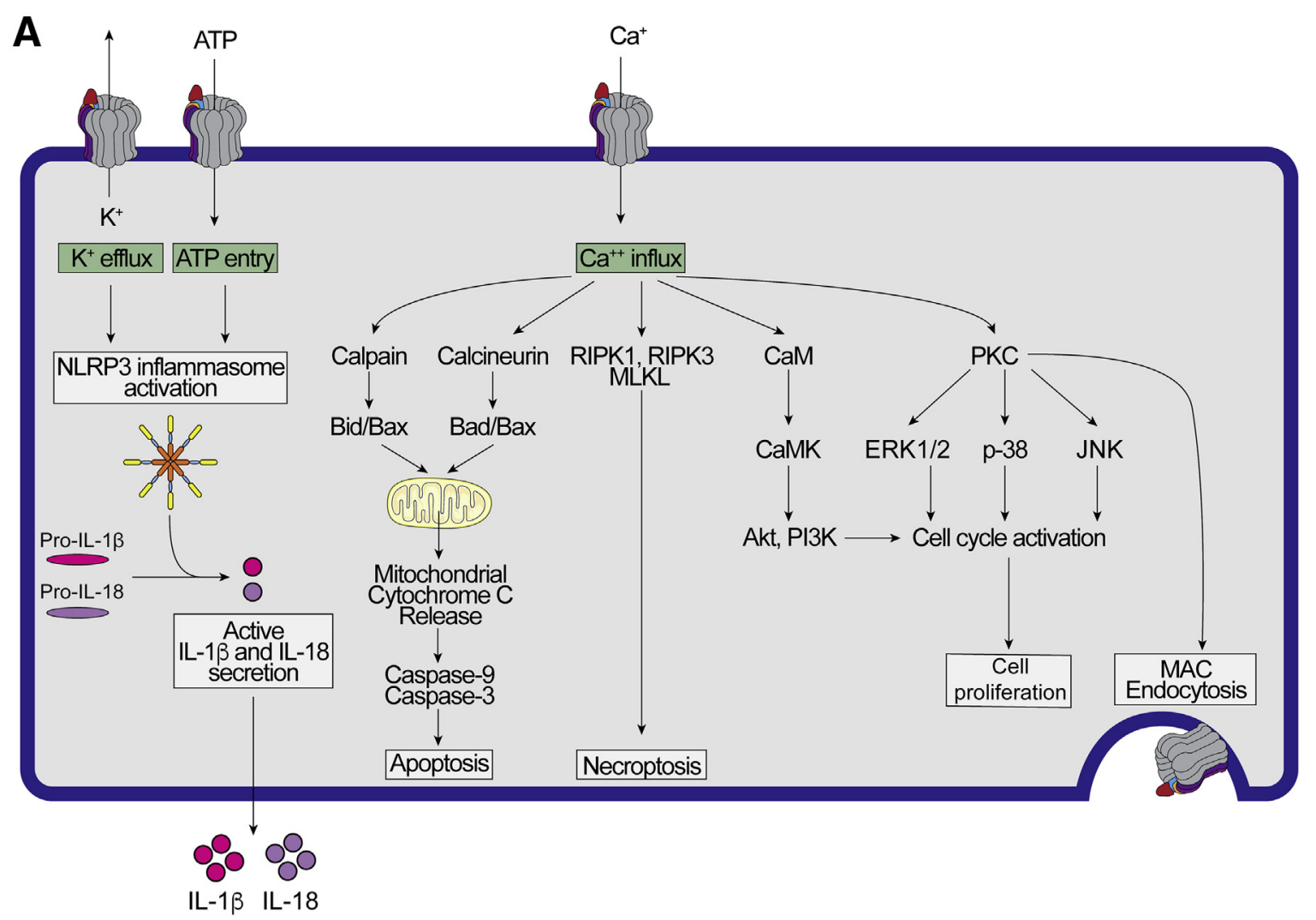

\section{B}

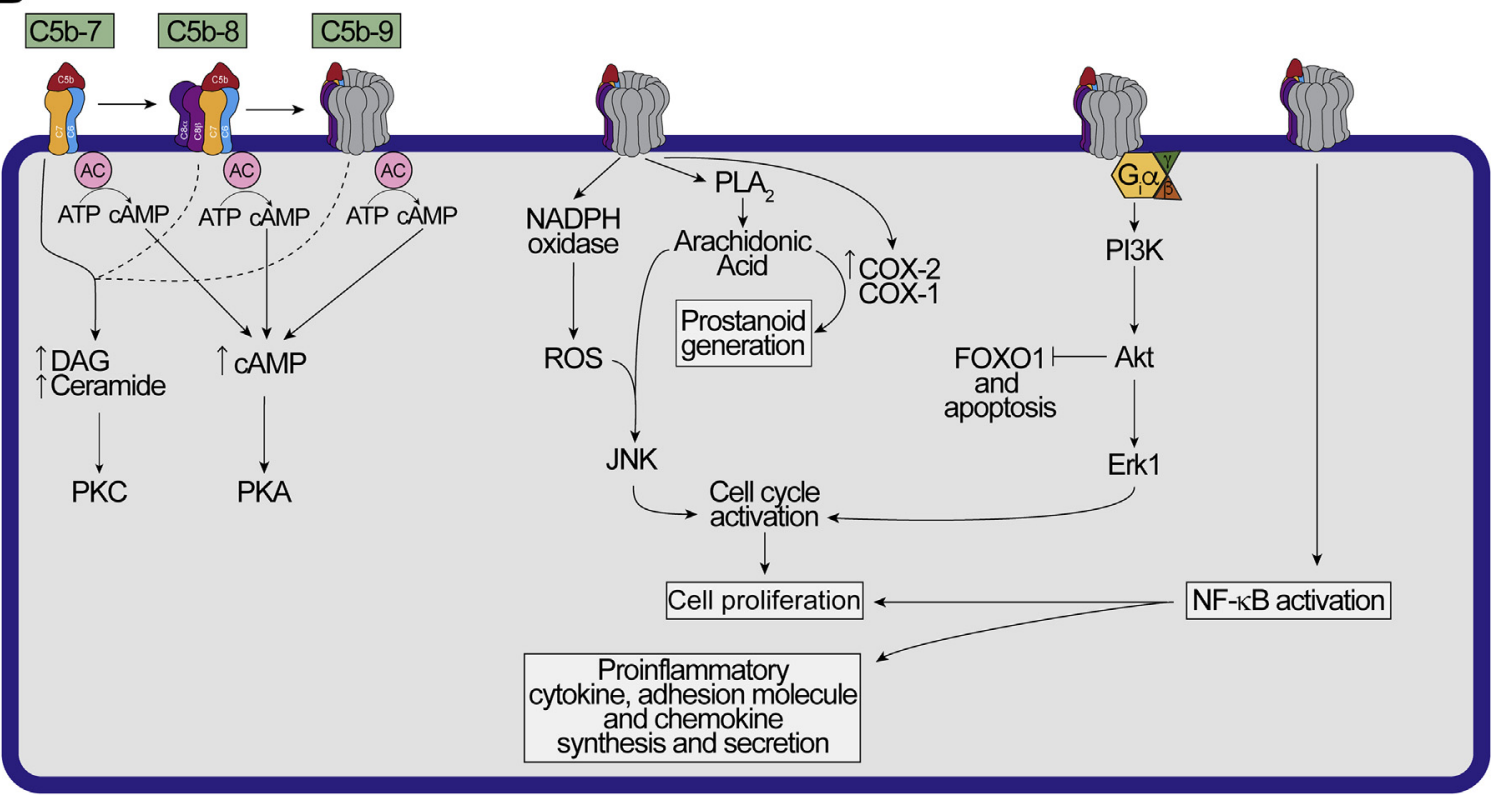

Figure 2 Membrane attack complex (MAC)-initiated intracellular signaling pathways lead to altered cell functions and cell activation. A: On complement activation, MAC deposition, and insertion into the plasma membrane, MAC can induce downstream prolytic and prosurvival, proliferative, and proinflammatory pathways that are dependent on MAC functioning as a pore and allowing small-molecule or ion flux, including potassium $\left(\mathrm{K}^{+}\right)$efflux, ATP entry, or calcium $\left(\mathrm{Ca}^{2+}\right)$ influx. B: MAC can induce signaling independent of membrane pore formation. MAC precursor complements $\mathrm{C} 5 \mathrm{~b}-7$ and $\mathrm{C} 5 \mathrm{~b}-8$ and MAC (C5b-9) can interact with signaling molecules and enzymes that induce the production of secondary messengers, such as cAMP, diacylglycerol (DAG), and ceramide. Resulting proliferative and proinflammatory signaling events induced include activation of phosphoinositide 3-kinase (PI3K)/Akt/forkhead box protein 01 (FOX01), extracellular signal-regulated kinase (ERK), and NF-KB signaling. Bax, Bcl-2-associated X protein; Bad, Bcl-2-associated death promoter; Bid, $\mathrm{Bcl}-2$ homology 3 domain (BH3) interacting domain death agonist; CaM, calmodulin; CaMK, CaM kinase; COX, cyclooxygenase; MLKL, mixed lineage kinase domain-like protein; JNK, Jun N-terminal kinase; $\mathrm{PLA}_{2}$, phospholipase $\mathrm{A}_{2}$; PKA, protein kinase $\mathrm{A}_{\text {; }}$ PKC, protein kinase $\mathrm{C}$; RIPK, receptor-interacting serine/ threonine-protein kinase. 
and activation of protein kinase $\mathrm{C}$, which, in turn, mediates activation of members of the mitogen-activated protein kinase cascade, such as extracellular signal-regulated kinase (ERK). ${ }^{26}$ In K562 human erythroleukemic cells, $\mathrm{Ca}^{2+}$. dependent activation of protein kinase $\mathrm{C}$ and protein kinase $\mathrm{C}$-mediated ERK activation increases the ability of the cells to resist MAC osmolysis by increasing membrane vesiculation and MAC internalization by endocytosis. ${ }^{26}$ In addition, MAC triggers $\mathrm{Ca}^{2+}$ intracellular influx in lipopolysaccharide-primed lung epithelial cells, leading to mitochondrial dysfunction and activating NLRP3 inflammasomes and proinflammatory IL-1 $\beta$ secretion. ${ }^{27}$

\section{MAC Signaling Initiated Independently of Ion Flux}

There is emerging evidence that MAC activates signaling in certain cell types independently of $\mathrm{Ca}^{2+}$ influx (ie, when an increase in cytosolic $\mathrm{Ca}^{2+}$ ion is prevented by removal of extracellular $\mathrm{Ca}^{2+}$ or by chelation of intracellular $\mathrm{Ca}^{2+}$ ). Similarly, signaling may occur when MAC is assembled from non-transmembrane MAC precursors that cannot form pores. For instance, $\mathrm{C} 5 \mathrm{~b}-7$ deposition can induce production of cAMP and lipid-derived signal messengers diacylglyceride and ceramide. Although these responses may be further increased with the assembly of C5b-8 and C5b-9, the response in the absence of $\mathrm{C} 8$ and $\mathrm{C} 9$ indicates that the activation of certain phospholipases is independent of ion flux $^{28,29}$ (Figure 2B). In glomerular epithelial cells (GECs) and tubular epithelial cells, MAC (C5b-9) assembly and deposition induces cytosolic phospholipase A2 to hydrolyze phospholipids at the plasma membrane, endoplasmic reticulum membrane, and nuclear envelope, leading to arachidonic acid production and release that is independent of $\mathrm{Ca}^{2+}$ flux. ${ }^{30}$ MAC significantly increases GEC expression of cyclooxygenase 2 and increased metabolism of arachidonic acid to prostanoids, exacerbating proteinuria in rat models of membranous nephropathy. MAC-induced cytosolic phospholipase A2 activation and phospholipid hydrolysis damages the endoplasmic reticulum membrane, inducing endoplasmic reticulum stress proteins bip and grp94 expression. ${ }^{31}$ MAC-induced stimulation of arachidonate metabolism also results in release of prostaglandin E2 from macrophages, leukotriene B4 from neutrophils, thromboxane $\mathrm{B} 2$ from human platelets, and prostanoids, IL1 , and reactive oxygen species from human monocytes. ${ }^{32,33}$

MAC can interact directly with $G_{i}$ protein, activating phosphatidylinositol 3-kinase/Akt/forkhead box protein $\mathrm{O} 1$ and ERK1 pathways that induce cell cycle activation ${ }^{34}$ (Figure 2B). In human aortic smooth muscle cells, MAC induces cell cycle entry and proliferation by activating mitogen-activated protein kinase pathways, phosphatidylinositol 3-kinase, and p70 S6 kinase. ${ }^{10}$ In cultured GECs, MAC-induced ERK-dependent activation of guanine nucleotide exchange factor H1 (GEF-H1), a guanine nucleotide exchange factor, and subsequent RhoA activation, providing a possible mechanism for MAC-induced actin cytoskeleton condensation and podocyte foot effacement in membranous nephropathy. ${ }^{35}$ Furthermore, MAC can cause lysosomal membrane permeabilization, blocking fusion of autophagosomes with the lysosome and impairing lysosomal degradation of autophagosomes in podocytes and tubular epithelial cells. ${ }^{36}$

MAC also triggers intracellular signaling independent of $\mathrm{K}^{+}$efflux, leading to inflammasome assembly and subsequent processing and secretion of IL-1 $\beta$ and IL-18. Although bacterial pore-forming proteins can elicit inflammasome assembly, this treatment activates both NOD-like receptor family CARD domain-containing protein 4 (NLRC4) and NLRP3 inflammasomes, ${ }^{37}$ whereas antibodymediated deposition of MAC on human endothelial cells (ECs) only activates NLRP3 inflammasomes. ${ }^{13}$ In this case, MAC signaling is initiated on $\mathrm{Rab}^{+} \mathrm{MAC}^{+}$endosomes and not on the plasma membrane so that NLRP3 inflammasome assembly in human endothelium can be abrogated by inhibiting clathrin-mediated endocytosis ${ }^{13,15}$ (Figure 3). Age-dependent increases in amyloid $\beta$ induce MAC deposition on rodent retinal pigment epithelium (RPE) and trigger inflammasome assembly, caspase- 1 activation, and secretion of IL-1 $\beta$ and IL-18. ${ }^{38}$ In systemic lupus erythematosus (SLE), engagement of the CD3/T-cell receptor (TCR) complex on $\mathrm{T}$ cells involves rewiring to spleen tyrosine kinase (Syk) rather than the tyrosine kinase homolog, zeta-chain-associated protein kinase 70 (ZAP70), and induces enhanced TCR-induced signaling T-cell responses; a study found that binding of immune complexes purified from SLE patients and MAC deposition on human naïve $\mathrm{CD}^{+} \mathrm{T}$ cells triggered activation of Syk and signaling by preferential recruitment of the fragment crystallizable region receptor gamma $(\mathrm{FcR} \gamma)$ chain. ${ }^{39}$ Because Syk has been described to be required for pro-IL-1 $\beta$ processing by and activation of the NLRP3 inflammasome, ${ }^{40}$ the implications of these MAC-mediated effects on enhanced pathogenic autoimmune $\mathrm{T}$-cell responses remain to be more fully studied.

\section{MAC Signaling Initiated by Internalization}

MAC has been shown to be removed from the cell surface of nucleated cells of multiple types, ${ }^{41,42}$ by endocytosis (internalization) and/or budding off of plasma membrane, a process termed ectocytosis. These processes allow for active and rapid removal of MAC lesions from the plasma membrane and cell recovery. Neutrophils use both endocytosis and ectocytosis of MAC, shedding MAC-enriched membrane vesicles with increased levels of cholesterol and diacylglycerol, suggestive of active lipid sorting. ${ }^{5,43,44}$ In K562 erythroleukemia cells, MAC endocytosis and loading into early endosomes is dependent on caveolin-1, implicating uptake through caveolae. ${ }^{45}$ MAC vesicular shedding from K562 cells is dependent on mortalin/glucose-regulated protein 75 (GRP75), a mitochondrial chaperone and member of the heat shock 


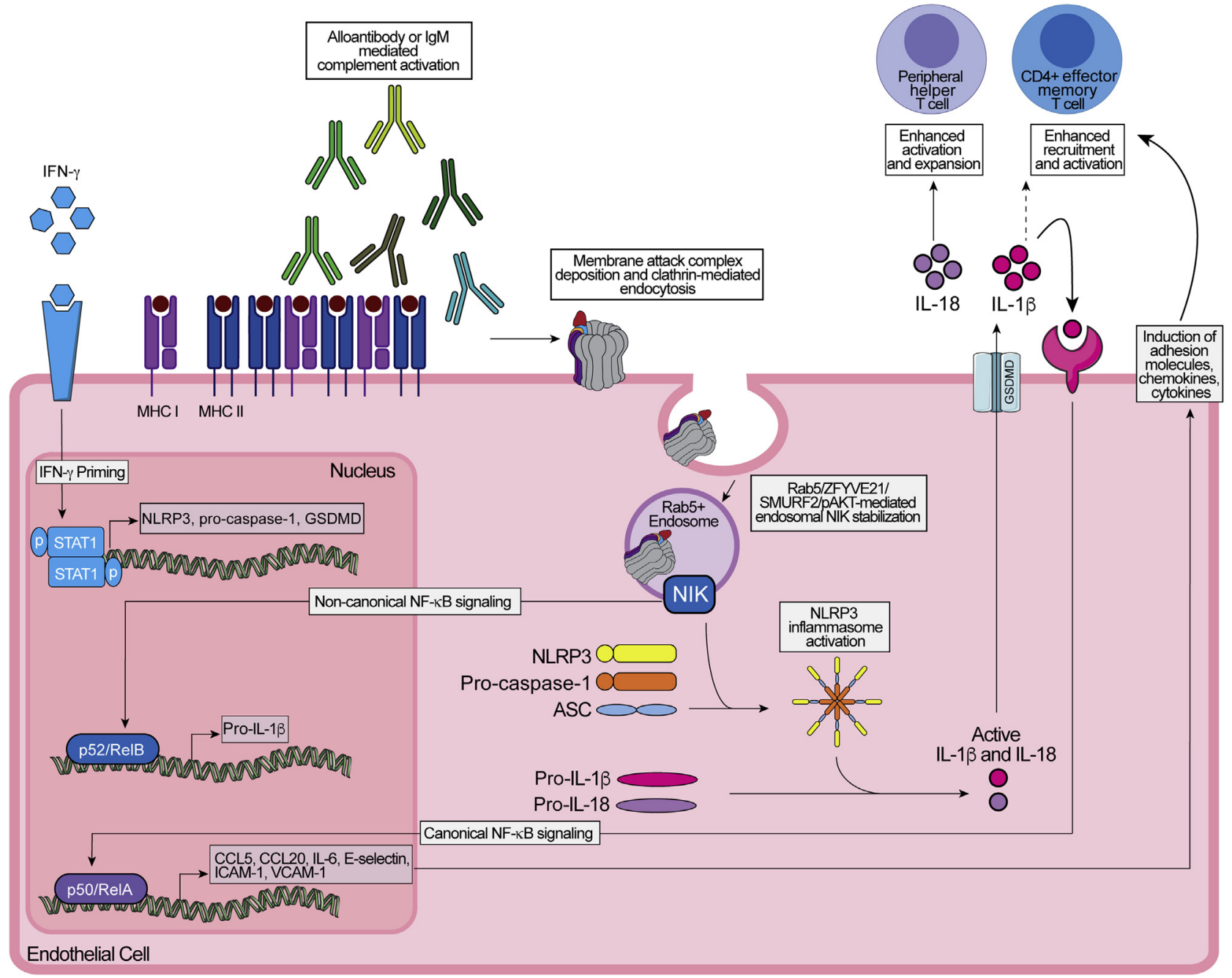

Figure 3 Internalized membrane attack complexes (MACs) activate interferon- $\gamma$ (IFN- $\gamma$ )-primed human endothelial cells (ECs) by a MAC/endosomal NF$\kappa B$-inducing kinase (NIK)/nucleotide-binding oligomerization domain-like receptor (NLR) family pyrin domain containing three (NLRP3) inflammasome/IL-1 signaling pathways and increase their ability to recruit and activate alloreactive T cells. Antibody-mediated complement activation leads to MAC deposition on the surface of IFN- $\gamma$-primed human ECs. MAC is internalized by a clathrin-mediated endocytosis and delivered to Ras-related protein Rab5 ${ }^{+}$endosomes. The Rab5/zinc finger FYVE-type containing 21 (ZFYVE21)/SMAD-specific E3 ubiquitin protein ligase 2 (SMURF2)/phosphorylated Akt signaling pathway modifies the phosphoinositide composition of $\mathrm{Rab5}^{+} \mathrm{MAC}^{+}$endosomes, which recruit and stabilize mitogen-activated protein kinase kinase kinase 14 [alias NF$\kappa \mathrm{B}$-inducing kinase (NIK)], preventing its tumor necrosis factor receptor-associated factor 3 -mediated polyubiquitinylation. Endosomal NIK activates noncanonical NF- $\kappa B$ signaling to synthesize pro-IL-1 $\beta$ and the assembly of an NLRP3 inflammasome that processes and secretes mature IL-1 $\beta$ and IL-18. IL$1 \beta$ feeds back on the ECs to induce proinflammatory genes through a canonical NF- $\kappa B$ pathway that increases the capacity of the ECs to activate alloreactive $\mathrm{CD}^{+} \mathrm{T}$ effect or memory cells. IL-18 selectively expands alloreactive peripheral helper T cells, an IL-21-producing T-cell subset. ASC, apoptosis-associated Speck-like protein containing CARD; CCL5, chemokine (C-C motif) ligand 5; CCL20, chemokine (C-C motif) ligand 20; GSDMD, gasdermin D; ICAM-1, intercellular adhesion molecule 1; MHC, major histocompatibility complex; VCAM-1, vascular cell adhesion molecule 1.

protein 70 family, that binds directly to $\mathrm{C} 9^{46}$ in potential cooperation with heat shock protein $90 .{ }^{47}$ Vesicular trafficking in RPE is critical for MAC removal and limiting inflammation. ${ }^{48}$ MAC deposition on rat kidney GECs in experimental membranous nephropathy is found in clathrin-coated pits, and MAC is also exocytosed into urine. $^{49}$ As noted above, alloantibody-mediated MAC deposited on the surface of human ECs that is internalized in a clathrin-mediated process and rapidly transferred to $\mathrm{Rab5}^{+}$endosomes within minutes ${ }^{9}$ (Figure 3). $\mathrm{MAC}^{+} \mathrm{Rab5}^{+}$endosomes act as a signaling platform by recruiting the Rab5 effector zinc finger FYVE-type containing 21 (ZFYVE21), leading to SMAD specific E3 ubiquitin protein ligase 2 (SMURF2)-dependent ubiquitinylation of phosphatase and tensin homolog (PTEN), followed by its proteasome-dependent degradation. ${ }^{12}$ This alters phosphoinositide composition of the $\mathrm{Rab5}^{+} \mathrm{MAC}^{+}$endosomes to allow for recruitment of signalosome components, phosphorylated Akt and NF- $\kappa \mathrm{B}$-inducing kinase (NIK). Binding to the endosome stabilizes NIK by preventing its tumor necrosis factor receptor-associated factor 3-mediated 
polyubiquitinylation and rapid proteosomal degradation. ${ }^{15}$ Endosomal NIK activates two responses: initiation of noncanonical NF- $\kappa \mathrm{B}$ signaling, leading to transcription; and translation of pro-IL-1 $\beta$ and NLRP3 recruitment from the endoplasmic reticulum and initiation of inflammasome assembly and caspase- 1 activation. Activated caspase- 1 cleaves and activates pro-IL$1 \beta$ and pro-IL-18 to form mature (bioactive) IL-1 $\beta$ and IL-18, respectively, and cleaves gasdermin $\mathrm{D}$, the amino terminal fragments of which form a pore that allows IL$1 \beta$ and IL-18 to be secreted from the cytosol. ${ }^{13}$ Circulating levels of interferon- $\gamma$, which acts on endothelium in situ to up-regulate major histocompatibility complex proteins, also prime ECs for MAC-induced NLRP3 inflammasome assembly and function by up-regulating expression of NLRP3, procaspase 1, and gasdermin D expression. ${ }^{13}$ IL-1 $\beta$, processed and released by MACactivated ECs, initiates autocrine/paracrine signaling and induces up-regulation of proinflammatory genes, including chemokines, cytokines, and adhesion molecules, through activation of canonical NF- $\kappa \mathrm{B}$ pathway. ${ }^{13}$ MAC induction of the EC NLRP3 inflammasome also led to IL-18 secretion from ECs, and IL-18 can act to selectively expand alloreactive peripheral helper $\mathrm{T}$ cells, an IL-21-producing T-cell subset, ${ }^{50}$ that may act on a variety of other cell types, including $B$ cells and endothelium. The net result of MAC-induced IL-1 $\beta$ (and possibly IL-18) secretion is to provide endothelium with an enhanced capacity to locally recruit and activate leukocytes, including alloreactive effector memory $\mathrm{T}$ cells. ${ }^{9,13}$ Prior studies have also shown that MAC deposition on human ECs induces activation dependent on NF- $\kappa \mathrm{B}$ activation, characterized by increased expression of IL-8, IL- $1 \alpha$, IL-1 $\beta$, E-selectin, intracellular adhesion molecule-1, vascular cell adhesion molecule-1, I $\kappa \mathrm{B} \alpha$, plasminogen activator inhibitor-1, and monocyte chemoattractant protein-1.,51,52 Previous reports inferring a direct link between MAC deposition and canonical NF- $\kappa \mathrm{B}$ signaling in ECs may need to be reconsidered in light of the role that inflammasomes and IL-1 $\beta$ have been shown to play in this response. ${ }^{8}$ In addition to ECs, MAC activation of NF- $\kappa \mathrm{B}$ signaling and gene transcription has also been observed in GECs, exacerbating proteinuria and experimental model of membranous nephropathy, ${ }^{53}$ and human vascular smooth muscle cells ${ }^{54}$ which may exacerbate the pathogenesis of atherosclerosis.

\section{MAC Signaling in Human Disease}

The effects of MAC have been studied in various cell types and disease settings, revealing intracellular signaling that increases cell activation, alters their functions, and promotes inflammation and disease pathogenesis. Numerous downstream signaling pathways have been implicated with various human and animal model cell types and different sources of complement and MAC activation. Although a unifying MAC signaling pathway is unlikely, there are common proliferative and proinflammatory signaling events that emerge, including activation of phosphatidylinositol 3-kinase/Akt/forkhead box protein O1 and ERK, inflammasome assembly, secretion of IL-1 $\beta$ and IL-18, and NF$\kappa \mathrm{B}$ signaling. Moreover, the context of MAC signaling and integration with the recent biophysical, kinetics, and structural advances will be important in future studies of MAC signaling.

\section{MAC in IRI}

MAC has been implicated as a mediator in ischemia/ reperfusion injury (IRI). ${ }^{55,56}$ IRI commonly occurs after restoration of blood after a prolonged period of occlusion, leading to widespread tissue damage, such as posttransplantation, stroke, or myocardial infarction. IRI induces EC changes that allow binding of natural IgM, mannose-binding lectin, or collectin-11, which can all activate complement, leading to MAC insertion and activation of the endothelium. ${ }^{57-59}$ IRI can cause alternative pathway complement activation on murine cells but classic pathway complement activation mediated by IgM on human cells. ${ }^{60}$ Allografts with IRI are associated with worse outcomes and are at higher risk for the development of graft rejection. Eculizumab is an anti-C5 monoclonal antibody that inhibits the generation of $\mathrm{C} 5 \mathrm{a}$ anaphylatoxin and C5b, which blocks formation of MAC. Several studies have investigated the effect of MAC inhibition on IRI. In experiments with a humanized mouse model of IRI, blocking terminal complement activation on human graft ECs lining a human coronary artery xenograft using anti-mouse C5 monoclonal antibody attenuated the IRI-exacerbated allograft vasculopathy. ${ }^{61}$ Similarly, murine complement inhibitors complement receptor 2 (CR2)-CD59a, which inhibits terminal MAC assembly, and CR2-complement receptor-1 related gene/ protein $\mathrm{Y}$ (Crry), which inhibits $\mathrm{C} 3$ activation, were found to be similarly protective against hepatic IRI. ${ }^{62}$ $\mathrm{CRIg} / \mathrm{FH}$, a complement receptor of the immunoglobulin superfamily (CRIg)-targeted complement inhibitor that connects the functional domains of CRIg and Factor $\mathrm{H}(\mathrm{FH})$, is protective in murine renal IRI by reducing complement activation C3d and MAC deposition in renal IRI, potentially via phosphatidylinositol 3-kinase/Akt activation. $^{63}$

\section{MAC in Transplant}

Transplant rejection, especially after the first postoperative year, is associated with complement-activating (fixing) donor-specific antibody (DSA) formation. ${ }^{64}$ Assessment of allograft biopsies frequently shows evidence of complement deposition, as detected as $\mathrm{C} 4 \mathrm{~d}$, but we have observed 
C5b-9 as well. ${ }^{12,13}$ Complement fixation is initiated by DSA binding nonself major histocompatibility complex I and II complexes on graft ECs, leading to up-regulation of proinflammatory genes characteristic of EC activation without causing cell death. Because MAC-activated ECs have enhanced ability to recruit and activate allogeneic memory $\mathrm{T}$ cells, ${ }^{9,12,13,15}$ this pathway may explain how DSA binding to graft ECs increases T-cell recruitment and secretion of interferon- $\gamma$, a cytokine that produces vasculopathic changes in the arterial wall. Allograft vasculopathy reduces organ perfusion, ultimately resulting in late graft failure. In organ transplantation, IRI not only exerts a direct effect on complement activation through the mechanisms described above, but also promotes the development of DSA and leads to sustained (or periodic) MAC activation of graft ECs. Mechanistically, the IgM-dependent MAC activation of human ECs induced by IRI leads to IL-18 secretion and selective expansion of IL-21-secreting peripheral helper $\mathrm{T}$ cells that promote B-cell production of DSA. ${ }^{50}$

\section{MAC in Cancer}

The interactions of cancer cells with MAC activation on and around cancer cells are complex. MAC has been found to activate pathways in cancer cells that inhibit death signals and induce mechanisms of evasion of complementdependent cytotoxicity, such as blocking MAC assembly and increasing MAC elimination from the cell surface. ${ }^{65}$ Increased presentation of CD59 on leukemic cancer cells reduces effectiveness of rituximab by inhibiting apoptosis $^{66,67}$ and on tumor cells leads to increased tumor progression in a model of neuroblastoma. ${ }^{68}$ Cancer cells activate protective pathways, including CD46, CD55, and CD59, to inhibit complement activation to reduce number of MAC inserted to counteract death signals. ${ }^{65}$

\section{MAC in Autoimmunity}

In SLE, autoantibodies forming immune complexes trigger complement activation, leading to cell membrane and soluble MAC. MAC deposition is associated with disease intensity and is a marker for poor treatment response. ${ }^{69}$ Altered CD55 and CD59 expression was found on peripheral blood cells from SLE patients with increased CD55 and CD59 lymphocytes, which may explain the cytopenia commonly found in SLE patients. ${ }^{70}$ A study also found evidence of complement activation and MAC deposits in brain lesions of patients with SLE. ${ }^{71}$ Although the exact initiation mechanism of rheumatoid arthritis is not known, it is thought that serum collagen autoantibodies can bind to cartilage components of antigen presented on the surface of articular cartilage, leading to complement activation. ${ }^{72}$ Evidence of complement activation and MAC have been found in the synovial fluid of rheumatoid arthritis patients $^{73}$ and on synovial ECs with significant MACmediated activation of the Rab5-ZFYVE21-SMURF2phosphorylated Akt axis, leading to enhanced immune cell infiltration. ${ }^{12}$ Soluble MAC was found to up-regulate osteoprotegerin expression and release by ECs. ${ }^{74}$ Although not generally considered a form of autoimmunity, osteoarthritis is also associated with complement activation with MAC deposition and signaling on synovial microvessels. ${ }^{12,75}$

\section{MAC in Membranous Nephropathy}

Idiopathic membranous nephropathy, one of the most common forms of nephrotic syndrome in adults, is characterized by immune complex and MAC deposition in the subepithelial space, causing thickening of the glomerular basement membrane and functional impairment of the glomerular capillary wall, manifested as proteinuria. An experimental model of membranous nephropathy is Heymann nephritis, and recent studies have found that M-type phospholipase $\mathrm{A}_{2}$ receptor as a major target antigen and IgG4 anti-phospholipase $\mathrm{A}_{2}$ receptor autoantibodies can activate complement by the lectin pathway. ${ }^{76}$ The deposition of MAC on podocytes initiates cellular dysfunction and is thought to be a critical step in membranous nephropathy development. ${ }^{36}$

\section{MAC in Age-Related Macular Degeneration}

Age-related macular degeneration is characterized by lesions at the RPE/choroid interface of the macular regions. MAC assembly and deposition by the alternative pathway may contribute to the pathogenesis of age-related macular degeneration. Oxidative stress was found to decrease levels of membrane-bound complement inhibitor CD59. ${ }^{77}$ MAC in RPE cells was found to increase vascular endothelial growth factor release and induce loss of barrier function, propagating choroidal neovascularization. ${ }^{77}$ MAC activation by lipofuscin or in combination with oxidative stress on RPE has also been observed to induce increased secretion of IL-6, IL8, and vascular endothelial growth factor. ${ }^{78,79}$ ECs of the choriocapillaries are the main sites on MAC deposition in the macula and can induce proinflammatory signaling, resulting in secretion of IL-6, IL-8, and vascular endothelial growth factor. $^{80,81}$ Age-related macular degeneration-associated mutations, discovered in patients, have been shown to alter the charged interface by which $\mathrm{C} 9$ polymerizes and drive both increased and decreased C9 self-polymerization, depending on the variant. ${ }^{19}$

\section{MAC in Other Diseases}

Additional diseases in which MAC signaling may be implicated include sleep apnea, ${ }^{82}$ osteoarthritis, ${ }^{12}$ Alzheimer disease, and atherosclerosis. Apolipoprotein E, which has been implicated to Alzheimer disease, was found to attenuate classic complement activation by high-affinity binding 
to the initiating $\mathrm{Clq}$ protein. ${ }^{83}$ In apolipoprotein E-deficient mice, complement activation led to leukocyte infiltration of the choroid plexus and reduction of $\mathrm{C} 5$ by siRNA decreased the complement-induced choroid plexus inflammation, atherosclerosis, and amyloid $\beta$-associated microglia. MAC, along with S-protein, C3d, and apolipoprotein $\mathrm{B}$, has been detected in human arterial tissues with atherosclerosis. $^{84}$ In CD59 and apolipoprotein E knockout mice, CD59 was found to protect against atherosclerosis by restricting MAC-mediated EC dysfunction and injury and foam cell formation. ${ }^{85}$

\section{New Insights into Therapeutic Strategies to Inhibit MAC Assembly, Signaling, and Proinflammatory Effects}

\section{Inhibiting MAC Assembly}

\section{CD59-Promoting Therapy}

Inhibiting MAC assembly with CD59 had been shown to attenuate complement-mediated pathologies in several disease models. In traumatic brain injury patients, MAC is implicated in secondary injury and neuronal loss in acute setting. Inhibition of MAC assembly by CD59a prevented microglial accumulation, mitochondrial stress, and axonal damage in a murine model of traumatic brain injury. ${ }^{86}$ In a mouse model of age-related macular degeneration, increased MAC deposition was observed on retinal pigment epithelium and increased with age-related macular degeneration. Inhibition of MAC using the murine complement inhibitor CR2-CD59 to inhibit MAC assembly reduced ocular injury severity. $^{87}$

\section{Anti-C5 Therapy}

Anti-C5 antibody binds to $\mathrm{C} 5$, preventing cleavage into $\mathrm{C} 5 \mathrm{a}$, the anaphylatoxin, and $\mathrm{C} 5 \mathrm{~b}$, a terminal complement component, and thus, inhibiting MAC formation. Anti-C5 monoclonal antibody (eculizumab) was approved for treatment of paroxysmal nocturnal hemoglobinuria and atypical hemolytic uremic syndrome. Anti-C5a receptor antibodies block the binding of $\mathrm{C} 5 \mathrm{a}$ to its receptor, C5aR, but do not inhibit MAC formation. Treatment with anti-C5 therapy, which blocks C5a and MAC formation and targeted at ischemic ECs, attenuated IRI injury. Anti-C5 inhibited complement activation and tissue damage in ex vivo rat model of renal IRI. ${ }^{88}$ In a humanized mouse model of allograft vasculopathy and IRI, anti-C5 antibody was effective in attenuating T-cell-mediated injury but not antiC5a, implicating C5b and terminal complement. ${ }^{61}$ In mouse disease models of atherosclerosis and Alzheimer disease, C5 was only made by the liver, allowing siRNA therapy, which naturally targets hepatocytes, to abrogate late complement signaling and reduction in disease severity. ${ }^{83}$ Complement receptor 1 is a complement regulatory protein that binds to $\mathrm{C} 3 \mathrm{~b}, \mathrm{C} 4 \mathrm{~b}, \mathrm{C} 1 \mathrm{q}$, and mannose-binding lectin to inhibit complement activation but is present in circulation at low concentrations; soluble complement receptor 1 treatment in patients undergoing cardiac surgery has been shown to prevent terminal complement activation and limit ischemic damage. $^{89}$

\section{Inhibition of MAC Signaling and Pro-Inflammatory Effects}

\section{NIK Inhibition}

MAC signaling leads to NIK stabilization on the surface of $\mathrm{Rab5}^{+}$endosomes, which induces NLRP3 inflammasome formation and noncanonical NF- $\mathrm{BB}$ signaling. The NLRP3 inflammasome leads to the secretion of active IL-1 $\beta$ and IL-18, and knockdown of NIK inhibited inflammasome assembly. ${ }^{13}$ Noncanonical $\mathrm{NF}-\kappa \mathrm{B}$ signaling contributes to IL-1 $\beta$ secretion by inducing sustained synthesis of pro-IL$1 \beta$. Inhibiting NIK may prevent the subsequent MAC signaling events, such as NLRP3 inflammasome activation and IL-1 $\beta$ secretion and signaling. Small-molecule NIK inhibitors have been screened for and tested in different disease contexts. ${ }^{90-92}$

\section{Inflammasome Inhibition}

MAC signaling activates the NLRP3 inflammasome, which leads to the activation of caspase- 1 that processes the proproteins into active IL-1 $\beta$ and IL-18. ${ }^{13}$ Inhibition of the inflammasome by the NLRP3 inhibitor MCC $950^{93}$ inhibited the formation of the MAC-induced NLRP3 inflammasome in human ECs lining a human coronary artery xenograft in vivo. Pharmacologic inhibitors of the inflammasome may be potential therapy to block downstream MAC-induced inflammasome activation and IL-1 secretion. Moreover, an additional advantage of inflammasome inhibition would be also blocking IL-18 secretion. MCC950 is being tested in early-phase clinical trials and evaluated for its anti-IL-1 effects. ${ }^{94}$ In addition, promoting endogenous regulatory proteins of the inflammasome, including caspase activation and recruitment domain [CARD16; constitutive photomorphogenesis protein 1 homolog (COP1)], CARD17 [inhibitory caspase recruitment domain CARD protein (INCA)], and CARD18 (ICEBERG), which are expressed only in humans, may be another strategy to inhibit the inflammasome. ${ }^{95}$

\section{Anti-IL-1 Therapy}

IL-1 receptor antagonist (or anakinra) is a competitive inhibitor and binds to IL-1 receptor 1 with similar affinity as IL- $1 \alpha$ and IL-1 $\beta$ without agonist behavior. Anti-IL-1 $\beta$ antibody (canakinumab) targets IL-1 $\beta$ and was shown in the Canakinumab Anti-Inflammatory Thrombosis Outcome Study (CANTOS) to decrease incidents of cardiovascular events in patients with atherosclerosis who had a myocardial infarction and incidentally also reduced cancer mortality. ${ }^{96}$ IL-1 $\beta$ is a major product of the NLRP3 inflammasome, which has been shown to be activated by MAC signaling. ${ }^{13,27,38}$ IL-1 $\beta$ released downstream of the MAC- 
induced NLRP3 inflammasome in ECs has been shown to mediate autocrine/paracrine proinflammatory EC activation that can be inhibited by IL-1 receptor antagonist. Inhibiting IL-1 signaling in the ECs diminished the MAC and IL-1 augmented ability of ECs to recruit and activate allogeneic memory $\mathrm{CD}^{+}{ }^{+} \mathrm{T}$ cells. ${ }^{13}$ In the humanized mouse chimeric model of artery allograft rejection, it was demonstrated that vascular cell-expressed IL-1 promotes allogeneic T-cell intimal infiltration and IL-1 receptor blockade partially reduces basal T-cell-mediated graft injury. ${ }^{97}$ Administration of anakinra to a small number of renal transplant patients appears to be safe and efficacious. ${ }^{98}$ Besides limited study in kidney transplant recipients with familial Mediterranean fever, ${ }^{99}$ canakinumab has yet to be assessed as a diseasemodifying therapy in transplant patients.

\section{References}

1. Murphy K, Travers P, Walport M, Janeway C: Janeway's Immunobiology. ed 8. New York, NY, Garland Science, 2012

2. Tegla CA, Cudrici C, Patel S, Trippe R 3rd, Rus V, Niculescu F, Rus H: Membrane attack by complement: the assembly and biology of terminal complement complexes. Immunol Res 2011, 51:45-60

3. Tschopp J, Podack ER, Muller-Eberhard HJ: Ultrastructure of the membrane attack complex of complement: detection of the tetramolecular C9-polymerizing complex C5b-8. Proc Natl Acad Sci U S A 1982, 79:7474-7478

4. Farkas I, Baranyi L, Ishikawa Y, Okada N, Bohata C, Budai D, Fukuda A, Imai M, Okada H: CD59 blocks not only the insertion of C9 into MAC but inhibits ion channel formation by homologous C5b8 as well as C5b-9. J Physiol 2002, 539:537-545

5. Morgan BP, Dankert JR, Esser AF: Recovery of human neutrophils from complement attack: removal of the membrane attack complex by endocytosis and exocytosis. J Immunol 1987, 138:246-253

6. Pilzer D, Gasser O, Moskovich O, Schifferli JA, Fishelson Z: Emission of membrane vesicles: roles in complement resistance, immunity and cancer. Springer Semin Immunopathol 2005, 27:375-387

7. Tedesco F, Pausa M, Nardon E, Introna M, Mantovani A, Dobrina A: The cytolytically inactive terminal complement complex activates endothelial cells to express adhesion molecules and tissue factor procoagulant activity. J Exp Med 1997, 185:1619-1627

8. Kilgore KS, Schmid E, Shanley TP, Flory CM, Maheswari V, Tramontini NL, Cohen H, Ward PA, Friedl HP, Warren JS: Sublytic concentrations of the membrane attack complex of complement induce endothelial interleukin-8 and monocyte chemoattractant protein-1 through nuclear factor-kappa B activation. Am J Pathol 1997, 150:2019-2031

9. Jane-Wit D, Manes TD, Yi T, Qin L, Clark P, Kirkiles-Smith NC, Abrahimi P, Devalliere J, Moeckel G, Kulkarni S, Tellides G, Pober JS: Alloantibody and complement promote T cell-mediated cardiac allograft vasculopathy through noncanonical nuclear factorkappaB signaling in endothelial cells. Circulation 2013, 128: 2504-2516

10. Niculescu F, Badea T, Rus H: Sublytic C5b-9 induces proliferation of human aortic smooth muscle cells: role of mitogen activated protein kinase and phosphatidylinositol 3-kinase. Atherosclerosis 1999, 142: $47-56$

11. Halperin JA, Taratuska A, Nicholson-Weller A: Terminal complement complex C5b-9 stimulates mitogenesis in 3T3 cells. J Clin Invest 1993, 91:1974-1978

12. Fang C, Manes TD, Liu L, Liu K, Qin L, Li G, Tobiasova Z, KirkilesSmith NC, Patel M, Merola J, Fu W, Liu R, Xie C, Tietjen GT, Nigrovic PA, Tellides G, Pober JS, Jane-Wit D: ZFYVE21 is a complement-induced Rab5 effector that activates non-canonical NFkappaB via phosphoinosotide remodeling of endosomes. Nat Commun 2019, 10:2247

13. Xie CB, Qin L, Li G, Fang C, Kirkiles-Smith NC, Tellides G, Pober JS, Jane-Wit D: Complement membrane attack complexes assemble NLRP3 inflammasomes triggering IL-1 activation of IFNgamma-primed human endothelium. Circ Res 2019, 124:1747-1759

14. Hadders MA, Bubeck D, Roversi P, Hakobyan S, Forneris F, Morgan BP, Pangburn MK, Llorca O, Lea SM, Gros P: Assembly and regulation of the membrane attack complex based on structures of C5b6 and sC5b9. Cell Rep 2012, 1:200-207

15. Jane-wit D, Surovtseva YV, Qin L, Li G, Liu R, Clark P, Manes TD, Wang C, Kashgarian M, Kirkiles-Smith NC, Tellides G, Pober JS: Complement membrane attack complexes activate noncanonical NFkappaB by forming an Akt + NIK + signalosome on Rab5+ endosomes. Proc Natl Acad Sci U S A 2015, 112:9686-9691

16. Morgan BP, Daniels RH, Watts MJ, Williams BD: In vivo and in vitro evidence of cell recovery from complement attack in rheumatoid synovium. Clin Exp Immunol 1988, 73:467-472

17. Dudkina NV, Spicer BA, Reboul CF, Conroy PJ, Lukoyanova N, Elmlund H, Law RH, Ekkel SM, Kondos SC, Goode RJ, Ramm G, Whisstock JC, Saibil HR, Dunstone MA: Structure of the poly-C9 component of the complement membrane attack complex. Nat Commun 2016, 7:10588

18. Parsons ES, Stanley GJ, Pyne ALB, Hodel AW, Nievergelt AP, Menny A, Yon AR, Rowley A, Richter RP, Fantner GE, Bubeck D, Hoogenboom BW: Single-molecule kinetics of pore assembly by the membrane attack complex. Nat Commun 2019, 10:2066

19. Menny A, Serna M, Boyd CM, Gardner S, Joseph AP, Morgan BP, Topf M, Brooks NJ, Bubeck D: CryoEM reveals how the complement membrane attack complex ruptures lipid bilayers. Nat Commun 2018, 9:5316

20. Serna M, Giles JL, Morgan BP, Bubeck D: Structural basis of complement membrane attack complex formation. Nat Commun 2016, 7:10587

21. Bayly-Jones C, Bubeck D, Dunstone MA: The mystery behind membrane insertion: a review of the complement membrane attack complex. Philos Trans R Soc Lond B Biol Sci 2017, 372: 20160221

22. Stratton D, Moore C, Antwi-Baffour S, Lange S, Inal J: Microvesicles released constitutively from prostate cancer cells differ biochemically and functionally to stimulated microvesicles released through sublytic C5b-9. Biochem Biophys Res Commun 2015, 460:589-595

23. Munoz-Planillo R, Kuffa P, Martinez-Colon G, Smith BL, Rajendiran TM, Nunez G: $\mathrm{K}(+)$ efflux is the common trigger of NLRP3 inflammasome activation by bacterial toxins and particulate matter. Immunity 2013, 38:1142-1153

24. Lusthaus M, Mazkereth N, Donin N, Fishelson Z: Receptor-interacting protein kinases 1 and 3, and mixed lineage kinase domain-like protein are activated by sublytic complement and participate in complement-dependent cytotoxicity. Front Immunol 2018, 9:306

25. Ziporen L, Donin N, Shmushkovich T, Gross A, Fishelson Z: Programmed necrotic cell death induced by complement involves a Biddependent pathway. J Immunol 2009, 182:515-521

26. Kraus S, Fishelson Z: Cell desensitization by sublytic C5b-9 complexes and calcium ionophores depends on activation of protein kinase C. Eur J Immunol 2000, 30:1272-1280

27. Triantafilou K, Hughes TR, Triantafilou M, Morgan BP: The complement membrane attack complex triggers intracellular $\mathrm{Ca} 2+$ fluxes leading to NLRP3 inflammasome activation. J Cell Sci 2013, 126: 2903-2913

28. Niculescu F, Rus H, Shin S, Lang T, Shin ML: Generation of diacylglycerol and ceramide during homologous complement activation. J Immunol 1993, 150:214-224

29. Carney DF, Lang TJ, Shin ML: Multiple signal messengers generated by terminal complement complexes and their role in terminal complement complex elimination. J Immunol 1990, 145:623-629 
30. Cohen D, Papillon J, Aoudjit L, Li H, Cybulsky AV, Takano T: Role of calcium-independent phospholipase A2 in complement-mediated glomerular epithelial cell injury. Am J Physiol Renal Physiol 2008, 294:F469-F479

31. Cybulsky AV, Takano T, Papillon J, Khadir A, Liu J, Peng H: Complement C5b-9 membrane attack complex increases expression of endoplasmic reticulum stress proteins in glomerular epithelial cells. J Biol Chem 2002, 277:41342-41351

32. Betz M, Seitz M, Hansch GM: Thromboxane B2 synthesis in human platelets induced by the late complement components C5b-9. Int Arch Allergy Appl Immunol 1987, 82:313-316

33. Hansch GM, Seitz M, Betz M: Effect of the late complement components C5b-9 on human monocytes: release of prostanoids, oxygen radicals and of a factor inducing cell proliferation. Int Arch Allergy Appl Immunol 1987, 82:317-320

34. Niculescu F, Rus H, van Biesen T, Shin ML: Activation of Ras and mitogen-activated protein kinase pathway by terminal complement complexes is $\mathrm{G}$ protein dependent. J Immunol 1997, 158: 4405-4412

35. Mouawad F, Aoudjit L, Jiang R, Szaszi K, Takano T: Role of guanine nucleotide exchange factor-H1 in complement-mediated RhoA activation in glomerular epithelial cells. J Biol Chem 2014, 289: 4206-4218

36. Liu WJ, Li ZH, Chen XC, Zhao XL, Zhong Z, Yang C, Wu HL, An N, Li WY, Liu HF: Blockage of the lysosome-dependent autophagic pathway contributes to complement membrane attack complex-induced podocyte injury in idiopathic membranous nephropathy. Sci Rep 2017, 7:8643

37. Gurcel L, Abrami L, Girardin S, Tschopp J, van der Goot FG: Caspase- 1 activation of lipid metabolic pathways in response to bacterial pore-forming toxins promotes cell survival. Cell 2006, 126: $1135-1145$

38. Zhao T, Gao J, Van J, To E, Wang A, Cao S, Cui JZ, Guo JP, Lee M, McGeer PL, Matsubara JA: Age-related increases in amyloid beta and membrane attack complex: evidence of inflammasome activation in the rodent eye. J Neuroinflammation 2015, 12:121

39. Chauhan AK, Moore TL: Immune complexes and late complement proteins trigger activation of Syk tyrosine kinase in human CD4(+) T cells. Clin Exp Immunol 2012, 167:235-245

40. Gross O, Poeck H, Bscheider M, Dostert C, Hannesschlager N, Endres S, Hartmann G, Tardivel A, Schweighoffer E, Tybulewicz V, Mocsai A, Tschopp J, Ruland J: Syk kinase signalling couples to the Nlrp3 inflammasome for anti-fungal host defence. Nature 2009, 459: 433-436

41. Scolding NJ, Morgan BP, Houston WA, Linington C, Campbell AK, Compston DA: Vesicular removal by oligodendrocytes of membrane attack complexes formed by activated complement. Nature 1989 , 339:620-622

42. Sims PJ, Wiedmer T: Repolarization of the membrane potential of blood platelets after complement damage: evidence for a $\mathrm{Ca}++$ -dependent exocytotic elimination of C5b-9 pores. Blood 1986, 68: $556-561$

43. Moskovich O, Fishelson Z: Live cell imaging of outward and inward vesiculation induced by the complement c5b-9 complex. J Biol Chem 2007, 282:29977-29986

44. Stein JM, Luzio JP: Ectocytosis caused by sublytic autologous complement attack on human neutrophils: the sorting of endogenous plasma-membrane proteins and lipids into shed vesicles. Biochem J 1991, 274:381-386

45. Moskovich O, Herzog LO, Ehrlich M, Fishelson Z: Caveolin-1 and dynamin-2 are essential for removal of the complement C5b-9 complex via endocytosis. J Biol Chem 2012, 287: 19904-19915

46. Pilzer D, Fishelson Z: Mortalin/GRP75 promotes release of membrane vesicles from immune attacked cells and protection from complement-mediated lysis. Int Immunol 2005, 17: $1239-1248$
47. Rozenberg P, Ziporen L, Gancz D, Saar-Ray M, Fishelson Z: Cooperation between Hsp90 and mortalin/GRP75 in resistance to cell death induced by complement C5b-9. Cell Death Dis 2018, 9:150

48. Lakkaraju A, Toops KA, Xu J: Should I Stay or Should I Go? Trafficking of Sub-Lytic MAC in the Retinal Pigment Epithelium. New York, NY, Springer New York, 2014. pp. 267-274

49. Kerjaschki D, Schulze M, Binder S, Kain R, Ojha PP, Susani M, Horvat R, Baker PJ, Couser WG: Transcellular transport and membrane insertion of the C5b-9 membrane attack complex of complement by glomerular epithelial cells in experimental membranous nephropathy. J Immunol 1989, 143:546-552

50. Liu L, Fang C, Fu W, Jiang B, Li G, Qin L, Rosenbluth J, Gong G, Xie CB, Yoo P, Tellides G, Pober JS, Jane-Wit D: Endothelial cellderived IL-18 released during ischemia reperfusion injury selectively expands $\mathrm{T}$ peripheral helper cells to promote alloantibody production. Circulation 2019, 141:464-478

51. Brunn GJ, Saadi S, Platt JL: Differential regulation of endothelial cell activation by complement and interleukin 1alpha. Circ Res 2006, 98 : 793-800

52. Saadi S, Holzknecht RA, Patte CP, Platt JL: Endothelial cell activation by pore-forming structures: pivotal role for interleukin-1alpha. Circulation 2000, 101:1867-1873

53. Mudge SJ, Paizis K, Auwardt RB, Thomas RJ, Power DA: Activation of nuclear factor-kappa B by podocytes in the autologous phase of passive Heymann nephritis. Kidney Int 2001, 59:923-931

54. Viedt C, Hansch GM, Brandes RP, Kubler W, Kreuzer J: The terminal complement complex C5b-9 stimulates interleukin-6 production in human smooth muscle cells through activation of transcription factors NF-kappa B and AP-1. FASEB J 2000, 14: $2370-2372$

55. Arumugam TV, Shiels IA, Woodruff TM, Granger DN, Taylor SM: The role of the complement system in ischemia-reperfusion injury. Shock 2004, 21:401-409

56. Zhou W, Farrar CA, Abe K, Pratt JR, Marsh JE, Wang Y, Stahl GL, Sacks SH: Predominant role for C5b-9 in renal ischemia/reperfusion injury. J Clin Invest 2000, 105:1363-1371

57. Marshall K, Jin J, Atkinson C, Alawieh A, Qiao F, Lei B, Chavin $\mathrm{KD}$, He S, Tomlinson S: Natural immunoglobulin M initiates an inflammatory response important for both hepatic ischemia reperfusion injury and regeneration in mice. Hepatology 2018, 67:721-735

58. Busche MN, Pavlov V, Takahashi K, Stahl GL: Myocardial ischemia and reperfusion injury is dependent on both IgM and mannosebinding lectin. Am J Physiol Heart Circ Physiol 2009, 297: H1853-H1859

59. McMullen ME, Hart ML, Walsh MC, Buras J, Takahashi K, Stahl GL: Mannose-binding lectin binds IgM to activate the lectin complement pathway in vitro and in vivo. Immunobiology 2006, 211 : 759-766

60. van der Pol P, Roos A, Berger SP, Daha MR, van Kooten C: Natural IgM antibodies are involved in the activation of complement by hypoxic human tubular cells. Am J Physiol Renal Physiol 2011, 300: F932-F940

61. Qin L, Li G, Kirkiles-Smith N, Clark P, Fang C, Wang Y, Yu ZX, Devore D, Tellides G, Pober JS, Jane-Wit D: Complement C5 inhibition reduces $\mathrm{T}$ cell-mediated allograft vasculopathy caused by both alloantibody and ischemia reperfusion injury in humanized mice. Am J Transplant 2016, 16:2865-2876

62. Marshall KM, He S, Zhong Z, Atkinson C, Tomlinson S: Dissecting the complement pathway in hepatic injury and regeneration with a novel protective strategy. J Exp Med 2014, 211:1793-1805

63. Hu C, Li L, Ding P, Li L, Ge X, Zheng L, Wang X, Wang J, Zhang W, Wang N, Gu H, Zhong F, Xu M, Rong R, Zhu T, Hu W: Complement inhibitor $\mathrm{CRIg} / \mathrm{FH}$ ameliorates renal ischemia reperfusion injury via activation of PI3K/AKT signaling. J Immunol 2018, 201:3717-3730 
64. Grafals M, Thurman JM: The role of complement in organ transplantation. Front Immunol 2019, 10:2380

65. Fishelson Z, Kirschfink M: Complement C5b-9 and cancer: mechanisms of cell damage, cancer counteractions, and approaches for intervention. Front Immunol 2019, 10:752

66. Bordron A, Bagacean C, Mohr A, Tempescul A, Bendaoud B, Deshayes S, Dalbies F, Buors C, Saad H, Berthou C, Pers JO, Renaudineau Y: Resistance to complement activation, cell membrane hypersialylation and relapses in chronic lymphocytic leukemia patients treated with rituximab and chemotherapy. Oncotarget 2018, 9: 31590-31605

67. Jia Y, Qi Y, Wang Y, Ma X, Xu Y, Wang J, Zhang X, Gao M, Cong B, Han S: Overexpression of CD59 inhibits apoptosis of Tacute lymphoblastic leukemia via AKT/Notch1 signaling pathway. Cancer Cell Int 2019, 19:9

68. Chen S, Caragine T, Cheung NK, Tomlinson S: CD59 expressed on a tumor cell surface modulates decay-accelerating factor expression and enhances tumor growth in a rat model of human neuroblastoma. Cancer Res 2000, 60:3013-3018

69. Wang S, Wu M, Chiriboga L, Zeck B, Belmont HM: Membrane attack complex (mac) deposition in lupus nephritis is associated with hypertension and poor clinical response to treatment. Semin Arthritis Rheum 2018, 48:256-262

70. Alegretti AP, Mucenic T, Merzoni J, Faulhaber GA, Silla LM, Xavier RM: Expression of CD55 and CD59 on peripheral blood cells from systemic lupus erythematosus (SLE) patients. Cell Immunol 2010, 265:127-132

71. Cohen D, Rijnink EC, Nabuurs RJ, Steup-Beekman GM, Versluis MJ, Emmer BJ, Zandbergen M, van Buchem MA, Allaart CF, Wolterbeek R, Bruijn JA, van Duinen SG, Huizinga TW, Bajema IM: Brain histopathology in patients with systemic lupus erythematosus: identification of lesions associated with clinical neuropsychiatric lupus syndromes and the role of complement. Rheumatology (Oxford) 2017, 56:77-86

72. Holers VM, Banda NK: Complement in the initiation and evolution of rheumatoid arthritis. Front Immunol 2018, 9:1057

73. Morgan BP, Daniels RH, Williams BD: Measurement of terminal complement complexes in rheumatoid arthritis. Clin Exp Immunol 1988, 73:473-478

74. Corallini F, Bossi F, Gonelli A, Tripodo C, Castellino G, Mollnes TE, Tedesco F, Rizzi L, Trotta F, Zauli G, Secchiero P: The soluble terminal complement complex (SC5b-9) up-regulates osteoprotegerin expression and release by endothelial cells: implications in rheumatoid arthritis. Rheumatology (Oxford) 2009, 48:293-298

75. Wang Q, Rozelle AL, Lepus CM, Scanzello CR, Song JJ, Larsen DM, Crish JF, Bebek G, Ritter SY, Lindstrom TM, Hwang I, Wong HH, Punzi L, Encarnacion A, Shamloo M, Goodman SB, Wyss-Coray T, Goldring SR, Banda NK, Thurman JM, Gobezie R, Crow MK, Holers VM, Lee DM, Robinson WH: Identification of a central role for complement in osteoarthritis. Nat Med 2011, 17: 1674-1679

76. Ma H, Sandor DG, Beck LH Jr: The role of complement in membranous nephropathy. Semin Nephrol 2013, 33:531-542

77. Rohrer B, Kunchithapautham K, Genewsky A, Strauss O: Prolonged SRC kinase activation, a mechanism to turn transient, sublytic complement activation into a sustained pathological condition in retinal pigment epithelium cells. Adv Exp Med Biol 2014, 801:221-227

78. Lueck K, Wasmuth S, Williams J, Hughes TR, Morgan BP, Lommatzsch A, Greenwood J, Moss SE, Pauleikhoff D: Sub-lytic C5b-9 induces functional changes in retinal pigment epithelial cells consistent with age-related macular degeneration. Eye (Lond) 2011, $25: 1074-1082$

79. Kunchithapautham K, Rohrer B: Sublytic membrane-attackcomplex (MAC) activation alters regulated rather than constitutive vascular endothelial growth factor (VEGF) secretion in retinal pigment epithelium monolayers. J Biol Chem 2011, 286: $23717-23724$
80. Skeie JM, Fingert JH, Russell SR, Stone EM, Mullins RF: Complement component C5a activates ICAM-1 expression on human choroidal endothelial cells. Invest Ophthalmol Vis Sci 2010, 51: $5336-5342$

81. Gerl VB, Bohl J, Pitz S, Stoffelns B, Pfeiffer N, Bhakdi S: Extensive deposits of complement C3d and C5b-9 in the choriocapillaris of eyes of patients with diabetic retinopathy. Invest Ophthalmol Vis Sci 2002, 43:1104-1108

82. Emin M, Wang G, Castagna F, Rodriguez-Lopez J, Wahab R, Wang J, Adams T, Wei Y, Jelic S: Increased internalization of complement inhibitor CD59 may contribute to endothelial inflammation in obstructive sleep apnea. Sci Transl Med 2016, 8: 320ra1

83. Yin C, Ackermann S, Ma Z, Mohanta SK, Zhang C, Li Y, Nietzsche S, Westermann M, Peng L, Hu D, Bontha SV, Srikakulapu P, Beer M, Megens RTA, Steffens S, Hildner M, Halder LD, Eckstein HH, Pelisek J, Herms J, Roeber S, Arzberger T, Borodovsky A, Habenicht L, Binder CJ, Weber C, Zipfel PF, Skerka C, Habenicht AJR: ApoE attenuates unresolvable inflammation by complex formation with activated C1q. Nat Med 2019, 25 : 496-506

84. Niculescu F, Rus HG, Vlaicu R: Immunohistochemical localization of C5b-9, S-protein, C3d and apolipoprotein B in human arterial tissues with atherosclerosis. Atherosclerosis 1987, 65:1-11

85. Wu G, Hu W, Shahsafaei A, Song W, Dobarro M, Sukhova GK, Bronson RR, Shi GP, Rother RP, Halperin JA, Qin X: Complement regulator CD59 protects against atherosclerosis by restricting the formation of complement membrane attack complex. Circ Res 2009, 104:550-558

86. Ruseva MM, Ramaglia V, Morgan BP, Harris CL: An anticomplement agent that homes to the damaged brain and promotes recovery after traumatic brain injury in mice. Proc Natl Acad Sci U S A 2015, 112:14319-14324

87. Schnabolk G, Beon MK, Tomlinson S, Rohrer B: New insights on complement inhibitor CD59 in mouse laser-induced choroidal neovascularization: mislocalization after injury and targeted delivery for protein replacement. J Ocul Pharmacol Ther 2017, 33: $400-411$

88. Durigutto P, Sblattero D, Biffi S, De Maso L, Garrovo C, Baj G, Colombo F, Fischetti F, Di Naro AF, Tedesco F, Macor P: Targeted delivery of neutralizing anti-C5 antibody to renal endothelium prevents complement-dependent tissue damage. Front Immunol 2017, 8: 1093

89. Lazar HL, Bokesch PM, van Lenta F, Fitzgerald C, Emmett C, Marsh HC, Ryan U: Soluble human complement receptor 1 limits ischemic damage in cardiac surgery patients at high risk requiring cardiopulmonary bypass. Circulation 2004, 110:II274-II279

90. Ren X, Li X, Jia L, Chen D, Hou H, Rui L, Zhao Y, Chen Z: A smallmolecule inhibitor of NF-kappaB-inducing kinase (NIK) protects liver from toxin-induced inflammation, oxidative stress, and injury. FASEB J 2017, 31:711-718

91. Brightbill HD, Suto E, Blaquiere N, Ramamoorthi N, SujathaBhaskar S, Gogol EB, Castanedo GM, Jackson BT, Kwon YC, Haller S, Lesch J, Bents K, Everett C, Kohli PB, Linge S, Christian L, Barrett K, Jaochico A, Berezhkovskiy LM, Fan PW, Modrusan Z, Veliz K, Townsend MJ, DeVoss J, Johnson AR, Godemann R, Lee WP, Austin CD, McKenzie BS, Hackney JA, Crawford JJ, Staben ST, Alaoui Ismaili MH, Wu LC, Ghilardi N: NF-кB inducing kinase is a therapeutic target for systemic lupus erythematosus. Nat Commun 2018, 9:179

92. Brightbill HD, Suto E, Blaquiere N, Ramamoorthi N, SujathaBhaskar S, Gogol E, Castanedo G, Jackson B, Haller S, Lesch J, Bents K, Everett C, Kohli PB, Linge S, Christian L, Barrett K, Jaochico A, Berezhkovskiy LM, Fan PW, Veliz K, Townsend M, DeVoss J, Johnson A, Godemann R, Lee WP, Austin CD, McKenzie B, Hackney JA, Crawford JJ, Staben S, Ismaili MHA, Wu LC, Ghilardi N: Selective inhibition of NF-kB inducing kinase 
(NIK) is therapeutically efficacious in IFN $\alpha$-accelerated lupus nephritis prone mice. J Immunol 2017, 198:217.4

93. Coll RC, Robertson AA, Chae JJ, Higgins SC, Munoz-Planillo R, Inserra MC, Vetter I, Dungan LS, Monks BG, Stutz A, Croker DE, Butler MS, Haneklaus M, Sutton CE, Nunez G, Latz E, Kastner DL, Mills KH, Masters SL, Schroder K, Cooper MA, O'Neill LA: A small-molecule inhibitor of the NLRP3 inflammasome for the treatment of inflammatory diseases. Nat Med 2015, 21:248-255

94. Schuh E, Gross CJ, Wagner D, Schluter M, Gross O, Kumpfel T: MCC950 blocks enhanced interleukin-1beta production in patients with NLRP3 low penetrance variants. Clin Immunol 2019, 203:45-52

95. Latz E, Xiao TS, Stutz A: Activation and regulation of the inflammasomes. Nat Rev Immunol 2013, 13:397-411

96. Ridker PM, MacFadyen JG, Thuren T, Everett BM, Libby P, Glynn RJ: Effect of interleukin-1beta inhibition with canakinumab on incident lung cancer in patients with atherosclerosis: exploratory results from a randomised, double-blind, placebo-controlled trial. Lancet 2017, 390:1833-1842

97. Rao DA, Eid RE, Qin L, Yi T, Kirkiles-Smith NC, Tellides G, Pober JS: Interleukin (IL)-1 promotes allogeneic $\mathrm{T}$ cell intimal infiltration and IL-17 production in a model of human artery rejection. J Exp Med 2008, 205:3145-3158

98. Mulders-Manders CM, Baas MC, Molenaar FM, Simon A: Periand postoperative treatment with the interleukin-1 receptor antagonist anakinra is safe in patients undergoing renal transplantation: case series and review of the literature. Front Pharmacol 2017, 8:342

99. Sendogan DO, Saritas H, Kumru G, Eyupoglu S, Sadioglu RE, Tuzuner A, Sengul S, Keven K: Outcomes of canakinumab treatment in recipients of kidney transplant with familial Mediterranean fever: a case series. Transplant Proc 2019, 51: 2292-2294 